
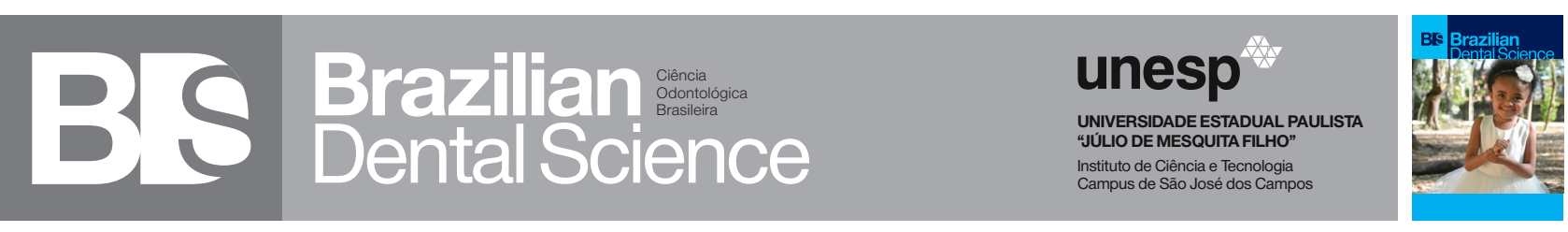

\title{
Stress and strain distributions on short implants with two different prosthetic connections - an in vitro and in silico analysis
}

Distribuições de tensão e microdeformação em implantes curtos com duas conexões protéticas diferentes - uma análise in vitro e in silico

João Paulo Mendes TRIBST ${ }^{1}$, Amanda Maria de Oliveira DAL PIVA ${ }^{1}$, Vinicius Anéas RODRIGUES ${ }^{1}$, Alexandre Luiz Souto BORGES ${ }^{1}$, Renato Sussumo NISHIOKA ${ }^{1}$

1 - São Paulo State University (Unesp) - Institute of Science and Technology - São José dos Campos - Department of Dental Materials and Prosthodontics - SP - Brazil.

\section{ABSTRACT}

Objective: An ideal biomechanics minimizes the stress between implant and bone that can provide success for osseointegrated implants. This study evaluated the strain concentration in surrounding tissue and stress in the components of two implants with different prosthetic connections through an in vitro and in silico methods. Methods: Twenty polyurethane blocks were divided into two groups $(n=10)$ followed by the installation of internal hexagon (IH) (AS Technology - Titanium Fix, São José dos Campos, Brazil) or locking taper implants (LT) (Bicon Dental Implants). For strain gauge (SG) method, four sensors were placed around the implants. For finite element analysis (FEA), the same block was modeled and analyzed. An axial load (30 kgf) was applied for both methodologies. The values of stress and strain were analyzed for correlation to SG. Results: For SG, LT presented a mean of strain most aggressive (-932) than IH (-632). For FEA, LT showed less stress (-547) then IH (-1169). Conclusion: For two implant's system, microstrain values capable to induce unwanted bone remodeling were not measured. However, for IH implant, the presence of a retention screw has the disadvantage to concentrate stress while a solid abutment dissipates the axial load through the implant that suggests a better performance for LT group.

\section{KEYWORDS}

Finite elements analyses; Dental implant; Strain gauge.

\section{RESUMO}

Objetivo: Uma biomecânica ideal que minimiza a tensão entre implante e osso pode proporcionar sucesso para implantes osseointegrados. Este estudo avaliou a concentração de deformação no tecido circundante e a tensão nos componentes de dois implantes com diferentes conexões protéticas através de métodos in vitro e in silico. Material e Métodos: Vinte blocos de poliuretano foram divididos em dois grupos ( $\mathrm{n}=10)$, seguido da instalação de hexágono interno (IH) (AS Tecnologia - Titanium Fix, São José dos Campos, Brasil) ou de implantes cone morse (LT) (Bicon Dental Implants). Para o método da extensometria (SG), foram colocados quatro sensores ao redor dos implantes. Para a análise por elementos finitos (FEA), o mesmo bloco foi modelado e analisado. Foi aplicada uma carga axial (30 kgf) para ambas as metodologias. Os valores de tensão e deformação foram analisados quanto à correlação com o SG. Resultados: Para SG, LT apresentou uma média de deformação mais agressiva (-932) que IH (-632). Para FEA, a LT mostrou menor tensão (-547) que IH (-1169). Conclusão: Para os dois sistemas implantes, os valores de microdeformação capazes de induzir remodelação óssea indesejada não foram medidos. No entanto, para o implante IH, a presença de um parafuso de retenção tem a desvantagem de concentrar a tensão, enquanto um pilar sólido dissipa a carga axial através do implante, o que sugere um melhor desempenho para o grupo LT.

\section{PALAVRAS-CHAVE}

Análise por elementos finitos; Implante dentário; Extensometria. 


\section{INTRODUCTION}

$\mathrm{T}_{\mathrm{t}}^{\mathrm{s}}$ he advancement of implantology is owed to the success of osseointegration processes, however, it still presents assembling challenges [1-3]. The knowledge of the masticatory mechanism forces on the system of prosthesis over implant is crucial for failure prevention [4-6]. When an implant-supported prosthesis is submitted to a certain load [6-8], it promotes bone remodeling $[6,9]$.

From a biomechanical point of view, the connection between abutment and implant must minimize the stress generated at the implant/bone interface [10], avoiding fatiguepromoted micro strains and consequently, bone resorption [11]. Another factor that promotes overloading is the use of short implants, as the crown/implant correlation is unfavorable [12] and provides a larger vertical lever arm.

The Finite Element Analysis (FEA) is a good alternative to help on the understanding of stress generated in the masticatory system since 1970 . Firstly, using a 2D model $[6,13]$ and from the 80's until today, 3D models $[2,3,14]$ have been used to develop and improve this tool for the study of biomechanical behavior of prostheses and implants.

FEA is the most affordable tool which simulates the same possible damages and presents similar results of an in vitro study $[15,16]$. In FEA, a mathematical model is used to envisage ideal conditions. However, in some situations, the correlation with an in vitro study may be necessary for further results $[16,17]$. The electronic strain $[3,18]$ and the photoelastic methodologies [19] may add as complementary results to FEA. For numerical stress values, the electronic strain gauge seems a good option [20]. The purpose of this study was to understand the influence of two different prosthetic connections on stress distribution and micro strains surrounding short implants.

\section{MATERIAL AND METHODS}

\section{Preparation of specimens}

Locking taper (LT) implants (BiconDental Implants, Boston, USA) and internal hexagon (IH) implants (AS Technology Titanium Fix, São José dos Campos, São Paulo, Brazil) were selected and equally distributed between two groups: LT and IH $(\mathrm{N}=20, \mathrm{n}=10)$. A stainless steel mold was used to manufacture 20 blocks of polyurethane (Polyurethane F16 Axson, Cercy, France), as manufacturer's recommendations. After polymerization, the material's surface was polished with \#220 to \#600 water granulation sandpaper (3M ESPE, São Paulo, São Paulo, Brazil) until reach the final dimension of $190 \mathrm{x}$ $30 \times 12 \mathrm{~mm}$.

For LT group, the blocks received locking taper implants. The perforations were made with 400:1 and $50 \mathrm{rpm}$ (Bicon Dental Implants). An implant insertion device was used to place the $4.5 \times 8 \mathrm{~mm}$ implants in the polyurethane blocks. The $10 \mathrm{~mm}$ height abutments were placed on the fixture with the system's dental mallet.

For IH group, the blocks received $\mathrm{IH}$ implants of $4.5 \times 8.5 \mathrm{~mm}$ (AS Technology Titanium Fix, São José dos Campos, Brazil). The perforations were made using a progressive sequence of drills at $1800 \mathrm{rpm}$, and the insertions of implants were performed with 14 $\mathrm{rpm}$ with a torque of $40 \mathrm{~N} / \mathrm{cm}$. On the fixture's seating platform, the $10 \mathrm{~mm}$ height abutments were screwed with a torque of $20 \mathrm{~N} / \mathrm{cm}$, using a progressive mechanical torque wrench.

\section{Strain Gauge Analysis}

The strain gauges (SGs) model PA-060120-L-040AB (Excel Sensors Ind. and Export Ltd., Embu, Brazil) were bonded on the surface of the polyurethane blocks with a thin layer of cyanoacrylate based adhesive (Loctite Super Bonder; São Paulo, Brazil). Four SGs were placed diametrically opposed and tangential at 
$1 \mathrm{~mm}$ around each implant (Figure 1). Terminal plates, responsible for the electrical connections, were attached on the blocks' external surface, connecting the SGs to an electrical signalconditioning unit (Model 5100 Scanner unit-System 5000B; Instruments Division Measurements Group, Inc., Raleigh, NC). Then, a static vertical load of $30 \mathrm{kgf}$ was applied during $10 \mathrm{~s}$ using a customized load application device [3]. The device's spherical tip was positioned on the center of each abutment. The magnitude of strain on each SG was recorded in units of micro strain $(\mu \mathrm{m} / \mu \mathrm{m})$.

Results were statistically analyzed by analysis of variance (ANOVA) - two way ("type of implant" - 2 levels and "strain gauge position" -4 levels $)$ followed by Tukey test $(\mathrm{P}<0.005)$, with the aid of specific software: GraphPad Prism (GraphPad Software, Version 4.00, 2003, La Jolla, USA) and MINITAB (Minitab, Version 14.12, 2004, State College, USA).

\section{Finite Element Analysis}

During pre-processing with Rhinoceros software (version 4.0 SR8McNell, Seattle, USA), a solid block was built to simulate the polyurethane block. The models were created with the same size of the blocks used in strain gauge analysis. Then, the evaluated areas were simulated on blocks' surfaces. LT implants were individually modeled following manufacturer's measurements ( $8.5 \times 4.5 \mathrm{~mm})$. Solid abutment were designed with $10 \mathrm{~mm}$ without shoulder and shows the slopes coming from the connection locking taper with walls diverging in the angle of $1.5^{\circ}$. The Boolean difference, a Rhinoceros command that trims the shared areas of selected polysurfaces with another set of polysurfaces, was made to the connection's internal walls that was in intimate contact with the abutment's external walls (Figure 2a-2g).

For the IH group, the implant was modeled with $8.5 \mathrm{~mm}$ height and $4.1 \mathrm{~mm}$ in diameter, with similar internal and external geometry threads. The abutment featured $10 \mathrm{~mm}$ height and $4.1 \mathrm{~mm}$ in external diameter base tapering to $3 \mathrm{~mm}$ at the upper end. A real size screw, responsible for the union with the implant, was modeled with an internal hexagon of $1.2 \mathrm{~mm}$ in diameter to simulate the key input torque and similar geometry threads along its length (Figure 2a-2g).

The final geometry was exported in STEP format to ANSYS software analysis (ANSYS 15.0, ANSYS Inc., Houston, USA) (Figure 2h-2k). All materials were considered homogeneous,

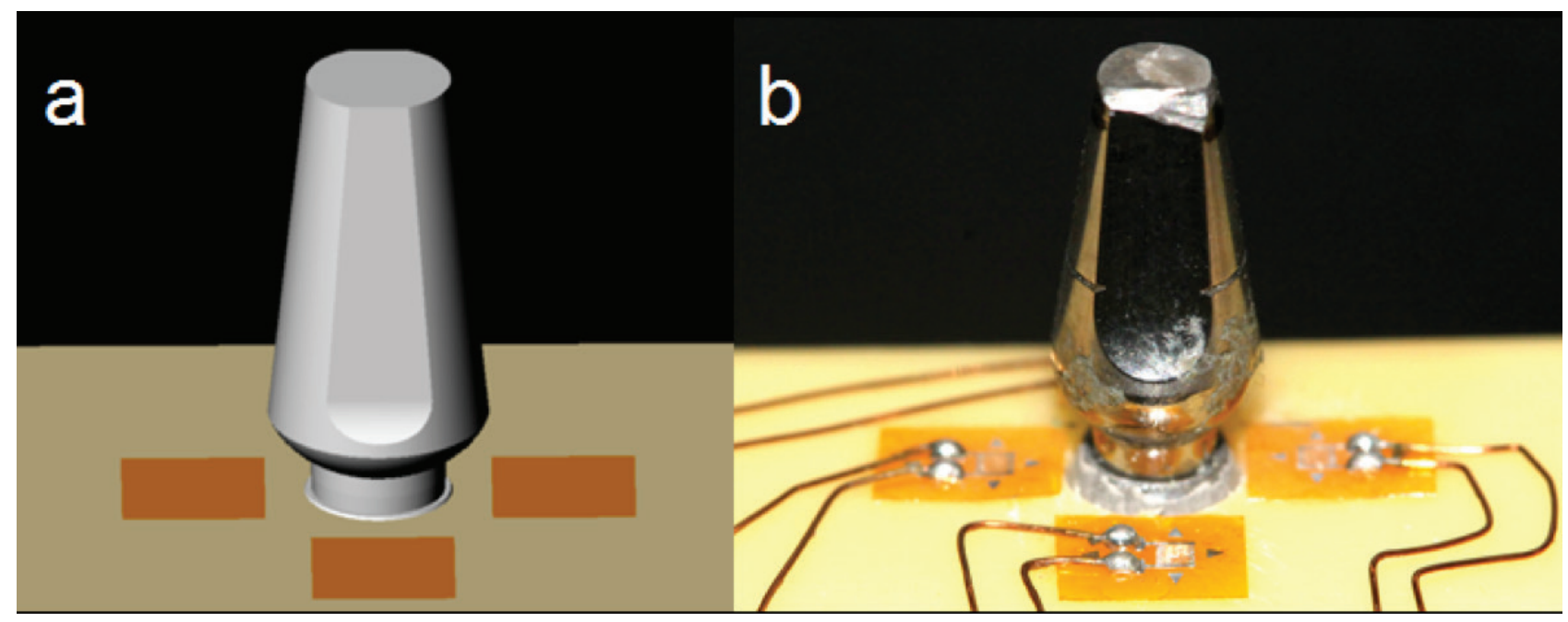

Figure 1-3D model and the experimental model for the LT group. a) 3D model with measurements area, b) Experimental model with strain gauges bonded in the same areas. 


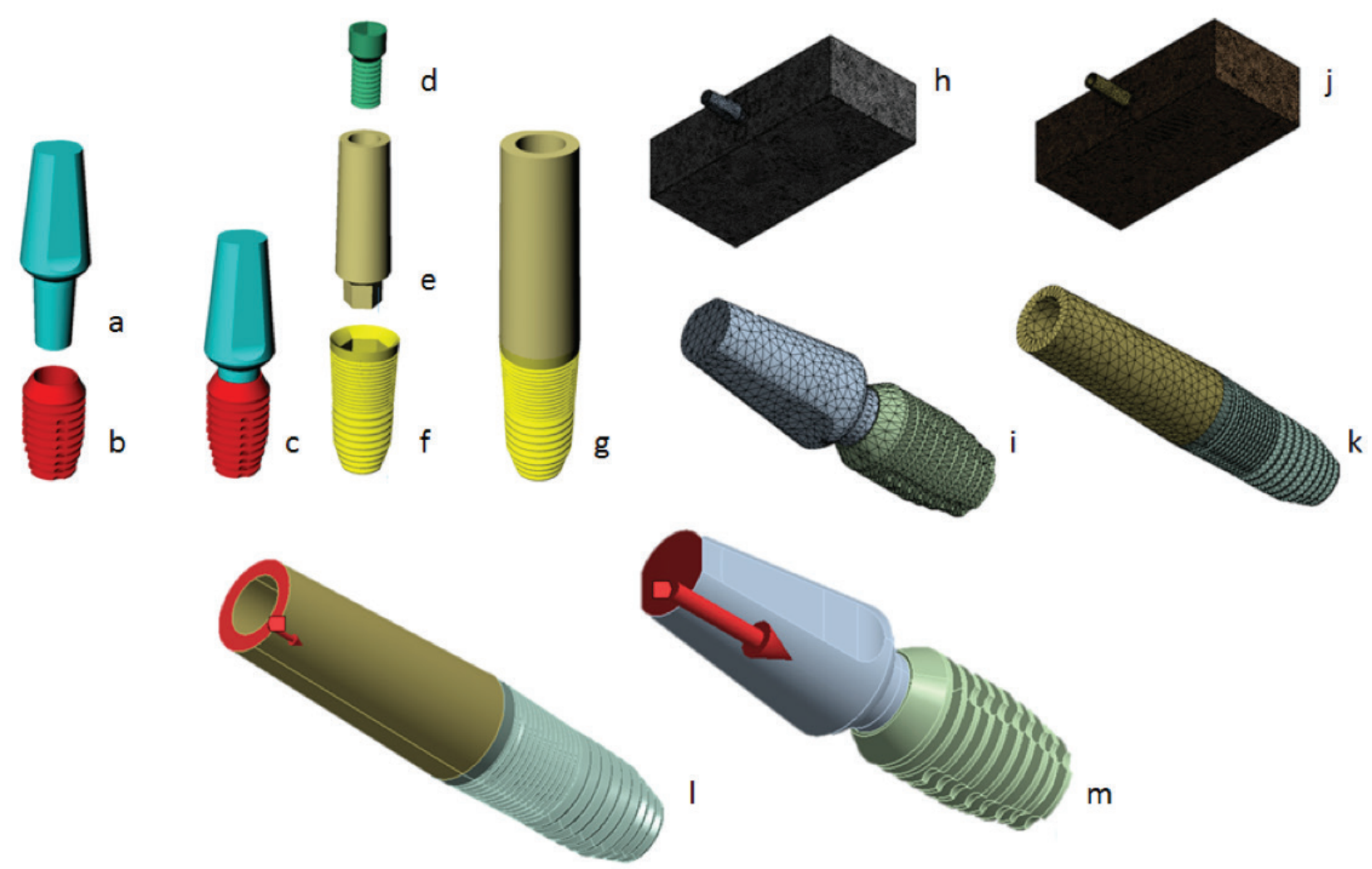

Figure 2 - a-m: a-g: 3D models of two-implant system. a) Solid abutment of LT system, b) LT implant, c) LT implant connected with abutment, d) Retention screw of $\amalg$ system, e) straight abutment, f) $\Perp$ implant, g) $\Vdash$ implant connected with abutment and retention screw; h-k: Mesh generated for the two implant systems. h) Implant LT placed into representative polyurethane block, i) Implant IH placed into representative polyurethane block, j) Mesh evidenced in abutment and implant LT, k) Mesh evidenced in abutment and IH implant; I and m: Load condition. I) IH implant with load condition in center of abutment and m) LT implant with load condition in the solid center of abutment.

isotropic, linear and elastic. Respective elastic modulus and Poisson's ratio were designated (Table 1). The mesh convergence test was used and the ideal size of the elements was $0.3 \mathrm{~mm}$. The number of nodes and tetrahedral solid elements were respectively 210,334 and 122,275 for Locking Taper and, 268,363 and 154,738 for Internal Hexagon. All contacts were considered completely bonded, excluding any loss of torque or rotational misfit.

Table 1 - Distribution of materials mechanical properties.

\begin{tabular}{|ccc|}
\hline Material & $\begin{array}{c}\text { Young's modulus } \\
\text { (GPa) }\end{array}$ & $\begin{array}{c}\text { Poisson's } \\
\text { ratio }\end{array}$ \\
\hline Ti-6Al-4V & 110 & $0.32[21]$ \\
\hline Fast Cast Polyurethane Resin & 3.6 & $0.30[22]$ \\
\hline
\end{tabular}

\section{RESULTS}

The experimental setup followed in vitro test, $30 \mathrm{kgf}$ axial load on each abutment (Figure 2l-m). The gradient stress generated in the polyurethane block was quantitatively analyzed for total strain (Figure 3), normal elastic strain (Figure 4), maximum elastic strain (Figure 5) and maximum principal stress (Figure 6).

Through two-way ANOVA, the factors "type of implant" (p <0.0000) and "strain gauge position" ( $\mathrm{p}<0.0000)$ were statistically significant (Table 2). For the experimental model (Strain gauge analysis), ANOVA showed statistical difference for both "type of implant" $(\mathrm{p}=0.000)$ and "strain gauge position" $(\mathrm{p}=0.000)$ factors. 

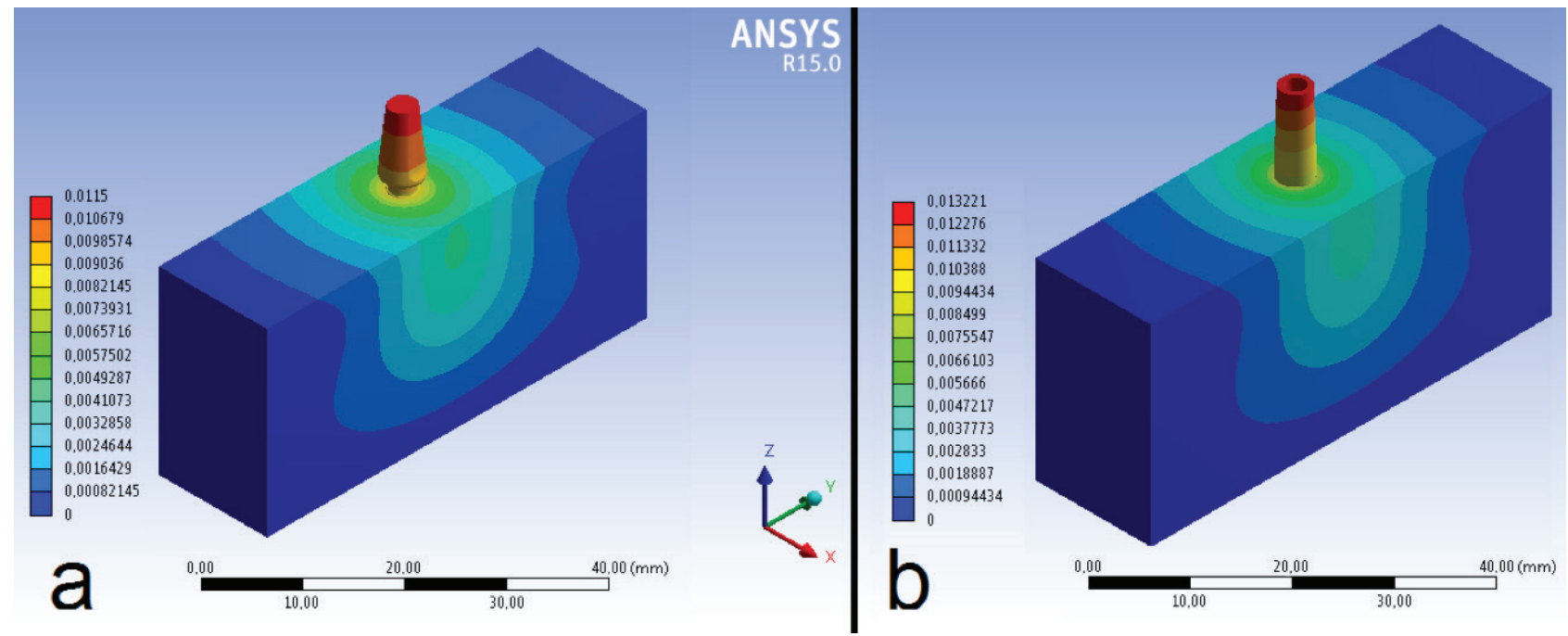

Figure 3 - a) Total strain showing the coherent energy dissipation in LT group, b) Total strain showing the coherent energy dissipation in $\mathrm{IH}$ group.

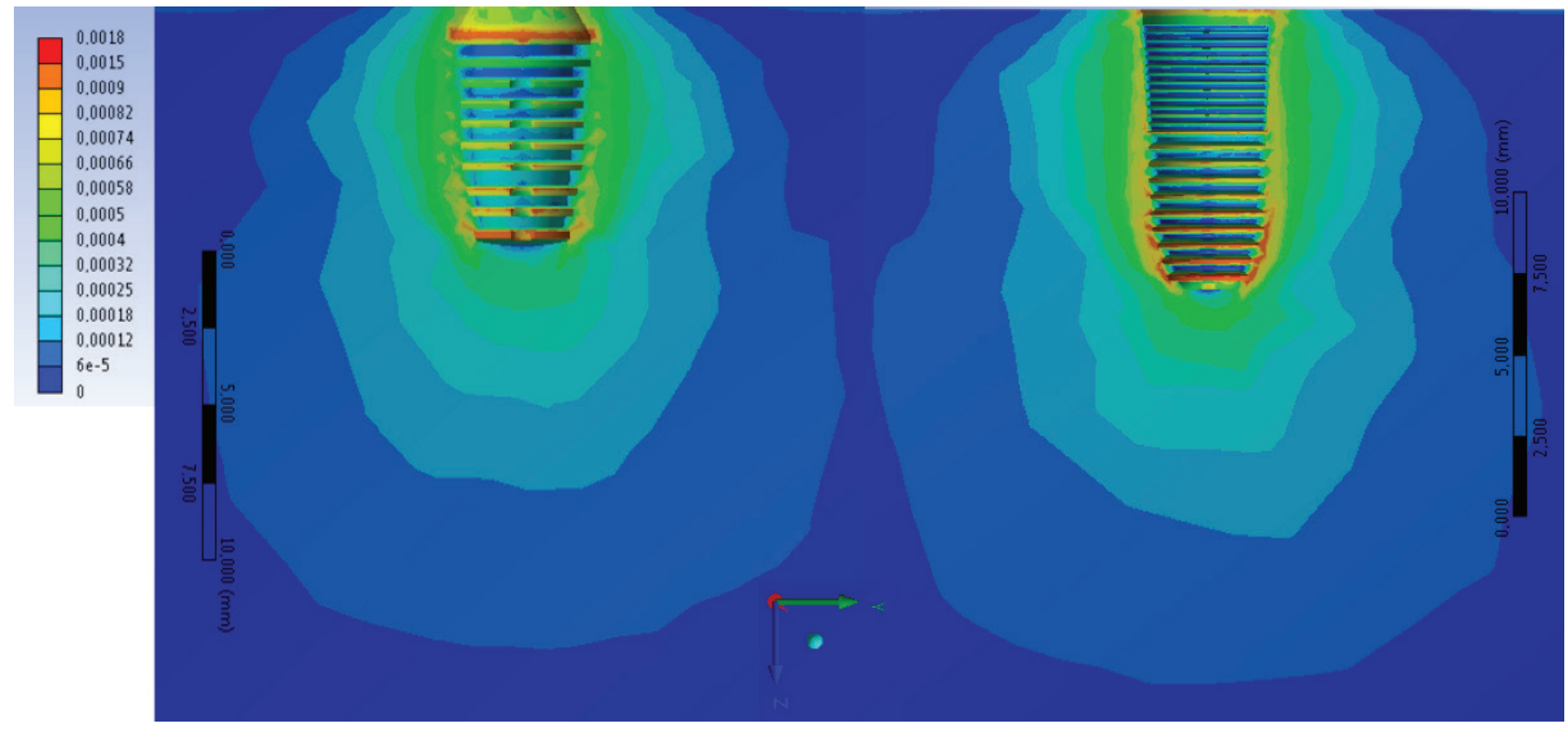

Figure 4 - Maximum elastic strain on both implant systems: LT (left) and IH (right). 

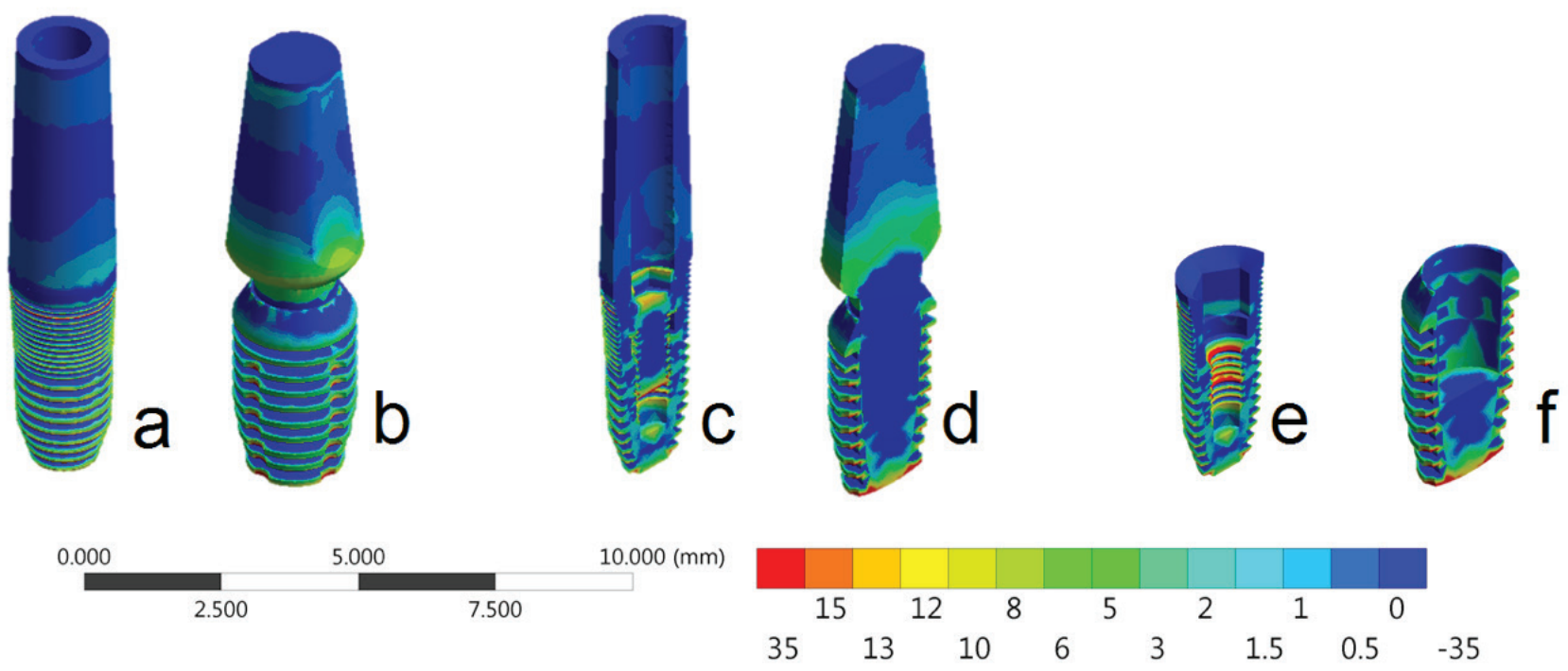

Figure 5 - a) Maximum principal stress (MPS) in IH implant system, b) MPS in LT implant system, c) MPS inside the IH implant system, d) MPS inside the LT implant system, e) MPS inside the $I H$ implant system without abutment and retention screw, f) MPS inside the LT implant system without the solid abutment.
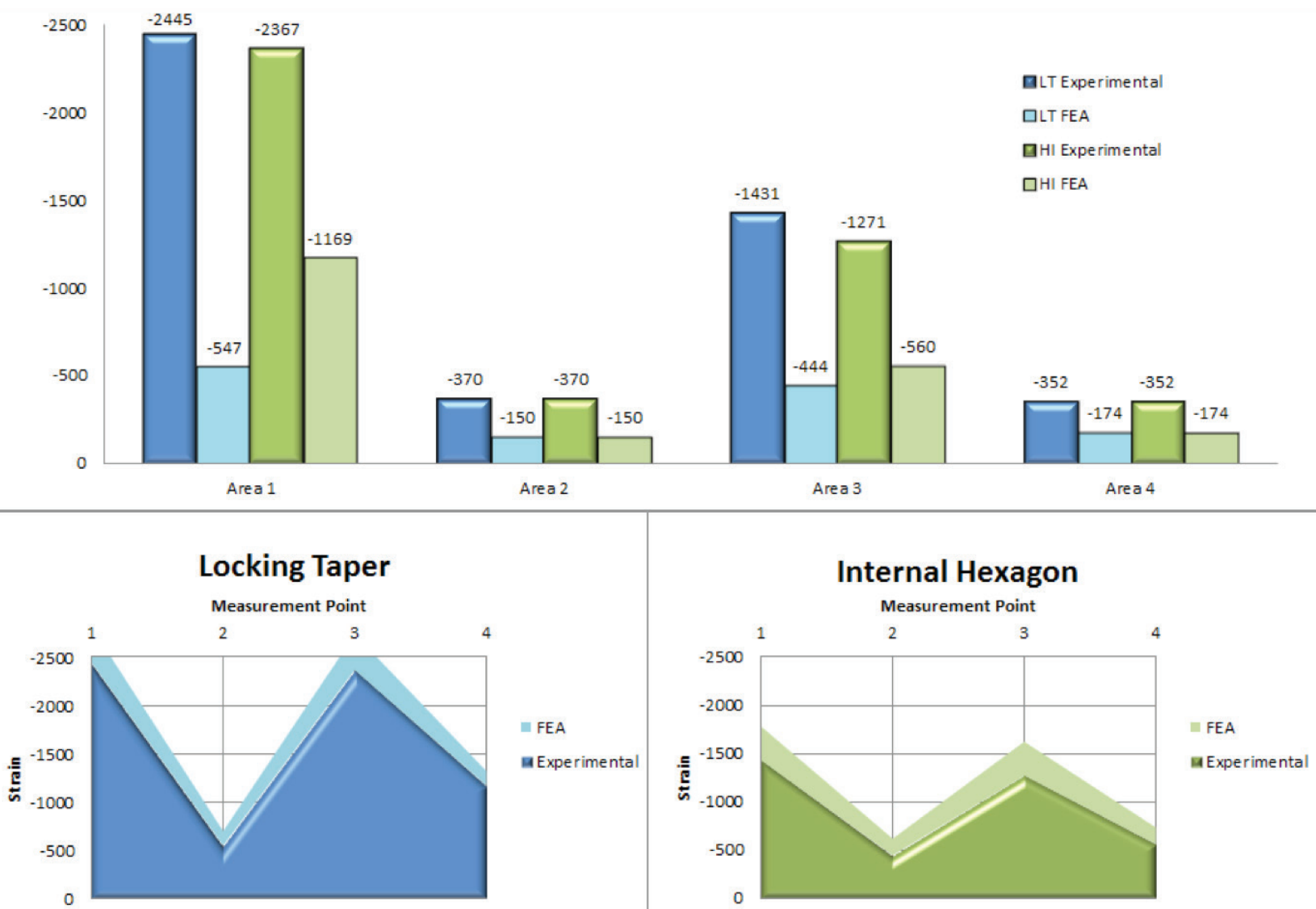

IFEA

axperimental

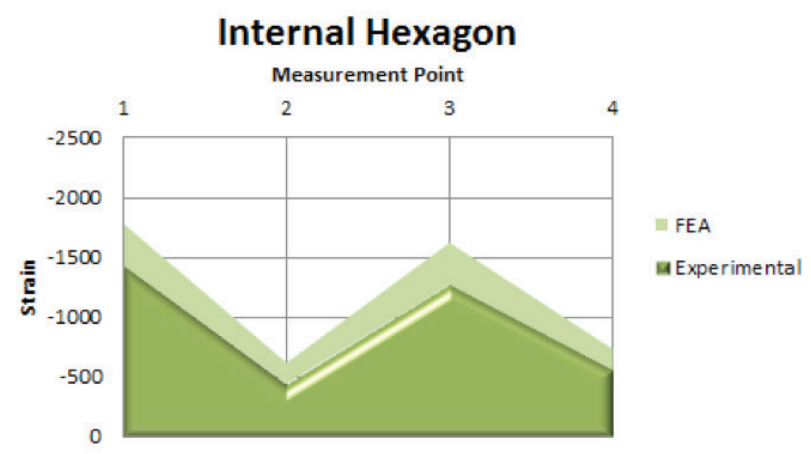

Figure 6 - Graph of micro strains for $L T$ and $॥$ groups. 
Table 2 - Tukey test (5\%) for the strain gauge position, $(n=5)$ per implant.

\begin{tabular}{cccccc} 
& LTImplant & \multicolumn{3}{c}{ HIImplant } \\
SGs & Mean & Group & SGs & Mean & Group \\
\hline 2 & -547.87 & A & 2 & -444.47 & A \\
\hline 4 & -1169.00 & A & 4 & -560.80 & A \\
\hline 3 & -2367.83 & B & 3 & -1271.93 & B \\
\hline 1 & -2444.97 & B & 1 & -1431.40 & B \\
\hline
\end{tabular}

\section{DISCUSSION}

Materials that are capable to simulate bone tissue are beneficial due to the reproduction of mechanical properties that allows results similar to the natural tissue [23]. Studies using bone tissue may present altered results according to the type of specimen and bone condition. Furthermore, when the focus is the ability to transmit masticatory forces by a system of complex geometries, it is necessary to use simplifications to achieve consistent results before biological studies [24]. The use of a healthy bone tissue could never mimic all the factors of human physiology. Thus, a material that simulates bone tissue could respond most questions arising from laboratory routine [25]. Polyurethane is an already validated material [23] on international standards ISO 14801: 2007, widely used for mechanical studies with implants [3,26], and it stands out for its human bone simulation capabilities, such as its elastic modulus is between the cortical and alveolar bone [23].

In FEA methodology, an ideal situation is simulated which may be a parameter with initial qualitative results to check what would be the ideal measurement of any instrument in the assembled system. In the logic of mathematical analysis, during a total strain, dissipated energy flows through geometries consistently. In Figure 3 , the behavior between groups showing the coherence of the system.

In all 20 polyurethane blocks, the biomechanical behavior follows a pattern with statistical difference between gauges in two positions: SG1 and SG3 in X axis, SG2 and SG4 in $\mathrm{Y}$ axis. This can be expressed in Figure 6, where the stress distribution in positions 1 and 3 showed higher values while the strain in regions 2 and 4 presented lower values. However, even with a similar strain distribution pattern, values showed a standard deviation that reinforces the need to perform a statistical analysis to better observe the correlation between the behaviors of gauges.

The gauges admeasurement is millimetrically sensitive to any variations, such as installation, minimal surface irregularities, gavel abutment installation friction, chemical interaction between the bonding agent and the transducer surface. These are factors that influence measuring, a situation which often arises from the applied methodology $[3,10,17]$.

To validate this study, the values of strain obtained by in vitro analysis were compared with the results calculated in FEA [16]. For this, the gauges area was virtually represented by a square, modeled on the block surface.

In Figure 6, it is possible to observe that the strain distribution is very similar for both methods which validate this $3 \mathrm{D}$ analysis. When two different methods are used to analyze the same situation it is possible to separate what should be considered as expected behavior for clinical extrapolation and to avoid erroneous results conclusions, although, it is not significant to be considered as consistent $[3,16,18]$.

With the certain of a valid model, a comparison between implants types could be made. Through a sagittal cut, it may be observed that the maximum principal stress (Fig.4) is shown in warmer colors which allow verification of the close relationship between implant and polyurethane. Thus, corroborating with other studies that used photoelasticity as method $[10,19]$. Such studies showed lower fringes of strain in conical implants when compared with hexagon connection system. Both models were 
very similar in values and isolines observed around the fixation but the LT showed mostly stress concentration in a cervical area and $\mathrm{IH}$ showed mostly stress in the apical direction.

To clarify the meaning of the values found and explain the difference between groups, it is necessary to verify the stress on the rigid structures of the specimens (Fig. 5): the abutment and implant set. Analyzing the maximum stress generated in implant's connection, the retaining screw in the IH (Fig.5) showed higher stress concentration. Since this screw is responsible for the connection between abutment and implant, this can make a IH system more fragile than LT. The impact on the threads of this screw tend to be high and it is one possibly reason to justify reports about loss of torque or even fracture of this piece [3,27]. LT implant platform presents higher values of micro strain in bone surface (Figure 4) but shows stress in the abutment $\backslash$ implant joint when compared with the IH connection implant (Figure 5).

Another important factor is the micro strain generated values in both methodologies (Figure 6). In situations in which the connection system inferred a difference between the average strain gauge's values, it is clear that the pathological limit of an unwanted bone resorption has not been reached [9]. Nonetheless, bone complication that may occur in these implants and do not appear to be associated with the type of prosthetic connection, but the wrong application/use and surgical planning.

\section{CONCLUSION}

Within this study's limitations, it may be concluded that:

- For two implant's system, micro strain values capable to induces unwanted bone remodeling were not measured. However, for IH implant, the presence of a retention screw has the disadvantage to concentrate stress while a solid abutment dissipates the axial load through the implant that suggests a better performance for LT group.

\section{Conflict of interest disclosure.}

The authors certify that they do not have commercial associations that might represent a conflict of interest in connection with the submitted manuscript.

\section{REFERENCES}

1. Esposito M, Hirsch JM, Lekholm U, Thomsen P. Biological factors contributing to failures of osseointegrated oral implants (II) Etiopathogenesis. Eur J Oral Sci. 1998 Jun;106(3):721-64.

2. Tribst JPM, Morais DC, Alonso AA, Dal Piva AMO, Borges ALS. Comparative three-dimensional finite element analysis of implantsupported fixed complete arch mandibular prostheses in two materials. J Indian Prosthodont Soc. 2017;17(3):255-60.

3. Rodrigues VA, Tribst JPM, Santis LR, Lima DR, Nishioka RS. Influence of angulation and vertical misfit in the evaluation of microdeformations around implants. Braz Dent Sci. 2017;20(1):32-9.

4. Rangert B, Jemt T, Jörneus L. Forces and moments on Brånemark implants. Int J Oral Maxillofac Implants. 1989 Fall;4(3):241-7.

5. Kayumi S, Takayama Y, Yokoyama A, Ueda N. Effect of bite force in occlusal adjustment of dental implants on the distribution of occlusal pressure: comparison among three bite forces in occlusal adjustment. Int J Implant Dent. 2015 Dec;1(1):14. Epub 2015 Jun 3.

6. Kumararama SS, Chowdhary R. Selection of dental implants based on masticatory load of the patient: A novel approach. Indian J Dent Res. 2017 May-Jun;28(3):309-313. doi: 10.4103/ijdr.IJDR_124_16.

7. Wiskott HW, Belser UC. Lack of integration of smooth titanium surfaces: a working hypothesis based on strains generated in the surrounding bone. Clin Oral Implants Res. 1999 Dec;10(6):429-44.

8. Frost HM. Skeletal structural adaptations to mechanical usage (SATMU): 1. Redefining Wolff's law: the bone modeling problem. Anat Rec. 1990 Apr;226(4):403-13.

9. Frost HM. Wolff's law and bone's structural adaptation to mechanical usage: an overview for clinicians. Angle Orthod. 1994;64(3):175-88.

10. Çehreli M, Duyck J, De Cooman M, Puers R, Naert I. Implant design and interface force transfer: a photoelastic and sttrain-gauge analysis. Clin Oral Implants Res. 2004 Apr;15(2):249-57.

11. Sotto-Maior BS, Rocha EP, Almeida EO, Freitas-Junior AC, Anchieta RB, Del Bel Cury AA. Influence of High insertion torque on implant placement - an anisotropic bone stress analysis. Braz Dent J. 2010;21(6):508-14.

12. Misch CE, Steigenga J, Barboza E, Misch-Dietsh F, Cianciola LJ. Short dental implants in posterior partial edentulism: a multicenter retrospective 6-year case series study. J Periodontol. 2006 Aug;77(8):1340-7.

13. Farah JW, Craig RG, Sikarskie DL. Photoelastic and finite element stress analysis of a restored axisymmetric first molar. J Biomech. 1973 Sep;6(5):511-20.

14. Borchers L, Reichart P. Three-dimensional stress distribution around a dental implant at different stages of interface development. J Dent Res. 1983 Feb;62(2):155-9.

15. Pick B, Meira JBC, Driemeier L, Braga RR. A critical view on biaxial and short-beam uniaxial flexural strength tests applied 
to resin composites using Weibull, fractographic and finite element analyses. Dent Mater. 2010 Jan;26(1):83-90. doi: 10.1016/j. dental.2009.09.002

16. Wang G, Zhang S, Bian C, Kong H. Verification of finite element analysis of fixed partial denture with in vitro electronic strain measurement. J Prosthodont Res. 2016 Jan;60(1):29-35. doi: 10.1016/j.jpor.2015.08.003. Epub 2015 Sep 16.

17. Ramos T, Braga DFO, Eslami S, Tavares PJ, Moreira PMGP. Comparison between finite element method simulation, digital image correlation and strain gauges measurements in a 3-point bending flexural test. Procedia Engineering. 2015;114:232-9.

18. de Vasconcellos LG, Nishioka RS, de Vasconcellos LM, Balducci I, Kojima AN. Microstrain around dental implants supporting fixed partial prostheses under axial and non-axial loading conditions, in vitro strain gauge analysis. J Craniofac Surg. 2013 Nov;24(6):e546-51. doi: 10.1097/SCS.0b013e31829ac83d.

19. Zanatta LC, Dib LL, Gehrke SA. Photoelastic stress analysis surrounding different implant designs under simulated static loading. J Craniofac Surg. 2014 May;25(3):1068-71. doi: 10.1097/ SCS.0000000000000829.

20. Tribst JPM, Dal Piva AMO, Borges ALS. Biomechanical tools to study dental implants: A literature review. Braz Dent Sci. 2016;19(4):5-11.

21. Benzing UR, Gall H, Weber H. Biomechanical aspects of two different implant-prosthetic concepts for edentulous maxillae. Int J Oral Maxillofac Implants. 1995;10(2):188-98.
22. Souza A, Xavier TA, Platt JA, Borges A. Effect of Base and Inlay Restorative Material on the Stress Distribution and Fracture Resistance of Weakened Premolars. Oper Dent. 2015;40(4):E15866.

23. Moretti Neto RT, Hiramatsu DA, Suedam V, Conti PC, Rubo $\mathrm{JH}$. Validation of an experimental polyurethane model for biomechanical studies on implant-supported prosthesis-compression tests. J Appl Oral Sci. 2011 Jan-Feb;19(1):47-51.

24. Al Nazer R, Lanovaz J, Kawalilak C, Johnston JD, Kontulainen S. Direct in vivo strain measurements in human bone-a systematic literature review. J Biomech. 2012 Jan 3;45(1):27-40. doi: 10.1016/j. jbiomech.2011.08.004. Epub 2011 Sep 1.

25. Dejak B, Młotkowski A, Langot C. Three-dimensional finite element analysis of molars with thin-walled prosthetic crowns made of various materials. Dent Mater. 2012 Apr;28(4):433-41. doi: 10.1016/j. dental.2011.11.019. Epub 2011 Dec 29.

26. Cho YE, Park EJ, Koak JY, Kim SK, Heo SJ, Park JM. Strain gauge analysis of occlusal forces on implant prostheses at various occlusal heights. Int J Oral Maxillofac Implants. 2014 Sep0ct;29(5):1034-41. doi: 10.11607/jomi.3040.

27. Maeda Y, Satho T, Sogo M. In vitro differences of stress concentrations for internal and external hex implant-abutment connections: a short communication. J Oral Rehabil. 2006 Jan;33(1):75-8.

\section{Amanda Maria de Oliveira Dal Piva} (Corresponding address)

Av. Eng. Francisco José Longo, no 777

Jardim São Dimas 